\title{
Surface runoff dominates stream source and hydrochemical composition in a semi-arid, thick, loess-covered catchment based on high resolution intra-rainfall sampling
}

\author{
Ze Tao ${ }^{1}$, Min $\mathrm{Li}^{1}$, Bing Cheng $\mathrm{Si}^{2}$, and Dyan Pratt ${ }^{2}$ \\ ${ }^{1}$ Northwest A\&F University \\ ${ }^{2}$ University of Saskatchewan
}

July 15, 2020

\begin{abstract}
The source and hydrochemical makeup of a stream reflects the connectivity between rainfall, groundwater, the stream, and is reflected to water quantity and quality of the catchment. However, in a semi-arid, thick, loess covered catchment, temporal variation of stream source and event associated behaviors are lesser known. Thus, the isotopic and chemical hydrograph in a widely distributed, deep loess, semi-arid catchment of the northern Chinese Loess Plateau were characterized to determine the source and hydrochemical behaviors of the stream during intra-rainfall events. Rainfall and streamflow were sampled during six hydrologic events coupled with measurements of stream baseflow and groundwater. The deuterium isotope $(2 \mathrm{H})$, major ions (Cl-, SO42-, NO3-, $\mathrm{Ca} 2+, \mathrm{K}+, \mathrm{Mg} 2+$, and $\mathrm{Na}+$ ) were evaluated in water samples obtained during rainfall events. Temporal variation of $2 \mathrm{H}$ and $\mathrm{Cl}-$ measured in the groundwater and stream baseflow prior to rainfall was similar; however, the isotope compositions of the streamflow fluctuated significantly and responded quickly to rainfall events, likely due to an infiltration excess, overland dominated surface runoff during torrential rainfall events. Time source separation using $2 \mathrm{H}$ demonstrated greater than $72 \%$ on average, the stream composition was event water during torrential rainfall events, with the proportion increasing with rainfall intensity. Solute concentrations in the stream had loglinear relationships with stream discharge, with an outling anomaly during an intra-rainfall event on Oct. 24, 2015. Stream Cl- behaved nonconservative during rainfall events, temporal variation of $\mathrm{Cl}$ - indicated a flush and washout at the onset of small rainfall events, a dilution but still high concentration pattern in high discharge and old water dominated in regression flow period. This study indicated that streamflow responded to rainfall events quickly and composition was dominated by overland flow. Stream isotope and hydrochemistry controlled by infiltration excess, overland flow indicated that stored water in the thick, loess covered areas were less connected with stream runoff. Solute transport may threaten water quality in the area, requiring further analysis of the performance of the eco-restoration project.
\end{abstract}

\section{Hosted file}

Taoze paper.docx available at https://authorea.com/users/343003/articles/469730-surfacerunoff-dominates-stream-source-and-hydrochemical-composition-in-a-semi-arid-thick-loesscovered-catchment-based-on-high-resolution-intra-rainfall-sampling

\section{Hosted file}

Taoze_figure.docx available at https://authorea.com/users/343003/articles/469730-surfacerunoff-dominates-stream-source-and-hydrochemical-composition-in-a-semi-arid-thick-loesscovered-catchment-based-on-high-resolution-intra-rainfall-sampling

\section{Hosted file}


Taoze_table.docx available at https://authorea.com/users/343003/articles/469730-surfacerunoff-dominates-stream-source-and-hydrochemical-composition-in-a-semi-arid-thick-loesscovered-catchment-based-on-high-resolution-intra-rainfall-sampling 